\title{
Mastaba 3541 North of Saqqara and the Archaeological
}

\section{Object discovered there*}

\section{Ali Mohamed Ahmed Ali**}

\section{ali.srhan201010@gmail.com}

The Saqqara necropolis is situated in the Western Desert approximately $24 \mathrm{~km}$ south of Cairo and immediately southwest of the modern village of Abusir (29 53E) And The site of Saqqara is the central portion of the Memphite necropolis which stretches from the northernmost sites of Abu Rawash, Giza to Zawiyet el Aryan, Abusir, Saqqara, South Saqqara and finally Dahshûr and Mazghuna in the south, for more than 30 kilometers ${ }^{1}$. The Early Dynastic tombs excavated at Saqqara/Abusir can be divided into three groups:

(1) The large 1st and 2nd Dynasty, Mastaba, tombs occupying the eastern edge of the North Saqqara plateau.

(2) Two areas of smaller tombs in the Abusir Valley; and (3) a series of underground galleries of the 2nd Dynasty (but no surviving superstructures) in the area of the Unas pyramid and pyramid temple (5th Dynasty). Excavations at North Saqqara by English archaeologists J.E. Quibell, C.M. Firth and W.B .Emery have exposed a series of large 1st and 2nd Dynasty tombs along the $55 \mathrm{~m}$ contour line on the eastern edge of the desert plateau, a location which would have made such structures highly visible from the cultivation ${ }^{2}$, North Saqqara was the focus of almost unbroken mortuary activity for a period exceeding 3000 years, and as development of this important site progressed it became necessary for the construction of new tombs and temples to take account of existing features. Also it was an exploration of the role that landscape and other factors may have played in the earliest phases of development at Saqqara, from the start of the First Dynasty until the reign of Netjerikhet.

\footnotetext{
* All thanks and appreciation to the work team of the wok central training unit and Cairo Giza training center at Saqqara and on their head Dr Bassem Gehad, Ahmed Hammad, Adel Abd-Elrahim, Samir Abd EI-Gaber and Atef, this is in addition to thanking professor Dr Sanna Gomma El-Rashedey and Dr AbuBakr Saad.

** PhD Researcher of Faculty of Archeology, South Valley University- Qena.

1 Francesco Raffaele Saqqara, Early Dynastic monuments (Dynasties 1-3), (2002).

2 Ana Traverse, Saqqara, North, Early Dynastic tombs, In Encyclopedia of the archaeology of ancient Egypt, K Bard ed, (Rutledge: London - New York 1999), 854-859.
} 
During this period, development at North Saqqara will have been relatively sparse and existing features will have presented a far less significant constraint to new construction. ${ }^{1}$

As early as 1912, a large, "archaic" cemetery was known to exist in north Saqqara, though it did not receive any serious attention until 1932, and it was still another twenty years before many of these results were published. The lack of enthusiasm for these excavations was probably due in no small part to the perception that they were poor "collector's sites". However, after some scholars came to believe that these were the tombs of Egypt's 1st Dynasty pharaohs, they received more attention, afterwards followed by much debate because the same rulers also had tombs at Abydos in Upper Egypt. One theory was that one of these sets of tombs, either at Saqqara or Abydos, was cenotaphs, or ceremonial tombs.

All of these tombs in both locations were severely plundered during antiquity, most were at least somewhat destroyed by fire, and there were no bodies found belonging to any of the early kings. However, further research seems to indicate that those at Saqqara were not the tombs of kings, but rather their highest officials, regardless of the fact that some of them were larger and more elaborate than the royal tombs at Abydos. ${ }^{2}$

B. Emery excavated more than twenty large mud brick mastaba tombs from the 1st dynasty at Saqqara. The results of Emery's exploits have been published in six extensive volumes. ${ }^{3}$

\section{The method of work:}

The squares located to the south of mastaba (S3537) ${ }^{4}$, approximately $30 \mathrm{~m}$ to the south west of Mastaba no.3537 excavated by Dr Bassem, and 20 $m$ to the North of Hagar's excavation (3538\&3539). I Using the Egyptian excavation Single recording system ${ }^{5}$, the work started in surface clean

1 Colin Reader, An early dynastic ritual landscape at North Saqqara: An inheritance from Abydos? In' The Journal of Egyptian Archaeology'(2017), 2.

2 John Watson, the 1st Dynasty Tombs of Saqqara in Egypt.

3 Rinus Ormeling, Revisiting Walter B. Emery at Saqqara: Exploring Emery's excavations, In a reevaluation of his field notes (1946-1956),Current Research in Egyptology 2016 Proceedings of the Seventeenth Annual Symposium, (Oxford 2017).1

4 Bassem Gehad, Et al, Archaeological Work at the Archaic Necropolis of North Saqqara the Excavation of tomb 3537, (2021), 1:117.

5 Geoffrey John Tassie and Lawrence Stewart Owens. Standards Of Archaeological Excavation A Field Guide To The Methodology Recording Techniques And Convention, 2010. 
deposit was silty sand, the second deposit was a wall UN completed, and the third deposit is Mudbrick structure.
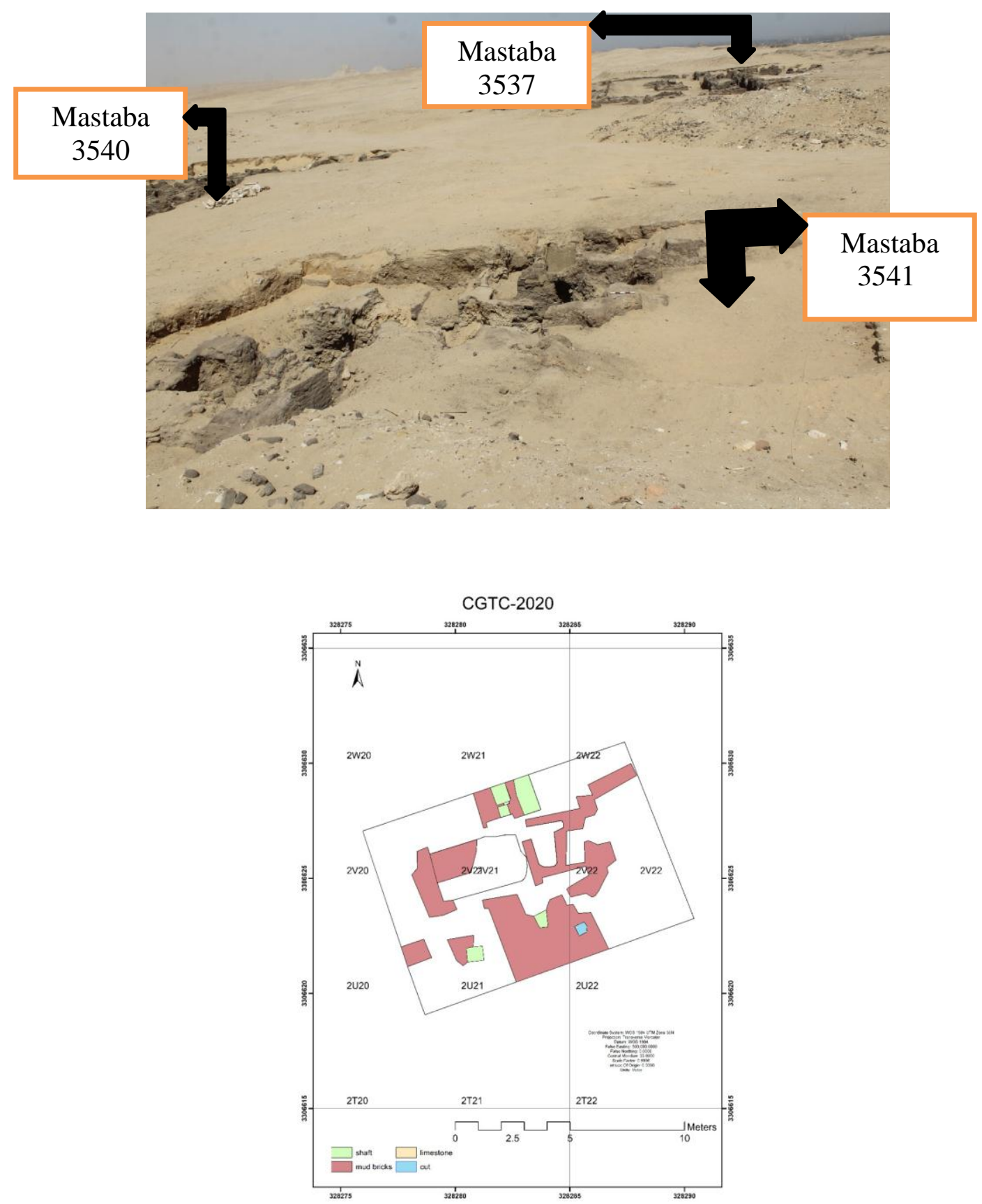


\section{Substructure:-}

The work was started on Squares sq\# 2720-2v21-2v22-2u21-2u222 the feature (A/a) silty sand Scattered in all squares, and the second deposit is Windblown sand anther sand Scattered in most squares, By studying pottery shards discovered in the First phase dating New king dom, and the I work in square $2 \mathrm{v} 21$ Fea\#21a $-2 \mathrm{v} 21-[\mathrm{A} / \mathrm{b}]$ its cut using as burial shaft width $1.55 \mathrm{c} . \mathrm{m}$ length $80 \mathrm{c} . \mathrm{m}$ and Height $2.70 \mathrm{c} . \mathrm{m}$ and its fill 21a-2721(A/b) silty sand, the burial shaft opened to burial chamber vaulted $[\mathrm{A} / \mathrm{n}]$ measurement it is $2.30 \times 1.83 \mathrm{c} . \mathrm{m}$ there are chamber hall in the north side of it may be small chamber empty Sizes it $86 \times 68 \mathrm{c} . \mathrm{m}$ may be used as a burial chilled Because When I Excavated the first deposit (A/a) inside this square, I found an oval-shaped wicker basket that may have been used as the object of a small coffin, during clean the area I found cut used as burial shaft 3 measurement $73 \times 65 \times 1.90 \mathrm{~cm}$ this burial shaft lead to same small burial chamber in the burial vaulted.

In the fill of burial shaft vaulted I found wooden coffin broken fea\#21a-2721- $<\mathrm{A} / \mathrm{s}>$ and found disturbed burial Wrapped in palm leaf Fea\# (A/t) during excavation method Found a wooden Oshabti statue .

During the completion of the Excavation in the northeastern corner of the square, found on rectangular burial shaft [A/f] Contain on 2 burial chamber, one is on the right Fea\#[A/i] and the other is on the left $[\mathrm{A} / \mathrm{k}]$ in the fill burial shaft $(\mathrm{A} / \mathrm{j})$ found on part of limestone Oshabti statue.

After the burial chamber is excavated Fea\# [A/i] I Excavate a second burial chamber $[\mathrm{A} / \mathrm{k}]$ The second burial chamber was excavated, which has a rectangular shape and is about $310 \times 210 \mathrm{c}$.m its fill is (A/l) silty sand, the important Excavate what discovered complete wooden coffin with wooden mask and mummy It is decorated with a faience bodice Taken Fea\# (A/x). 

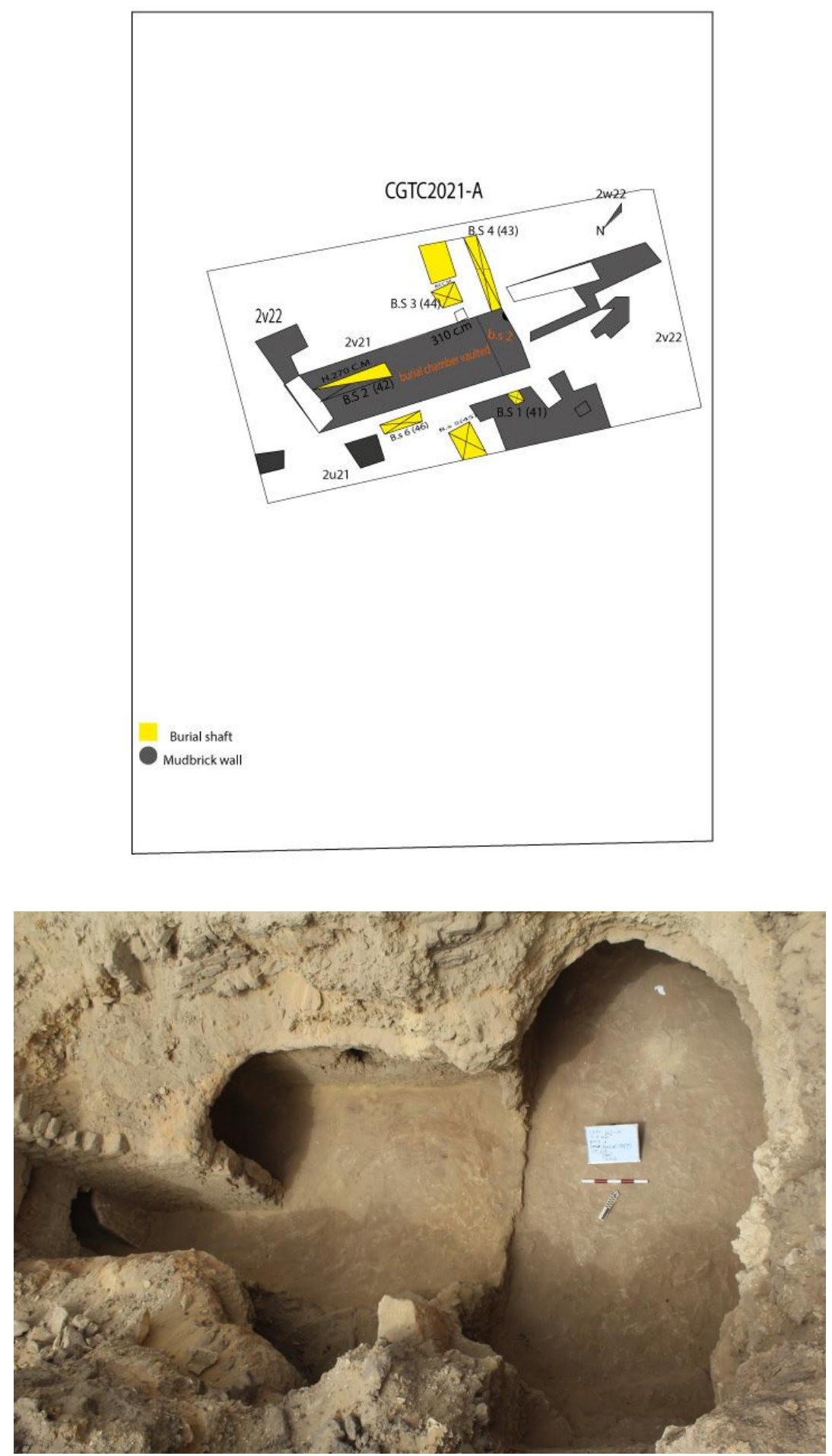
Burial chamber 2:

Burial shaft 2 southern burial shaft 4 celling of the burial chamber is very bad condition.

Burial shaft 3:

Small ensclogn wall from mudbrick management is $65 \times 73 \times 190$ c.m, there burial chamber in burial shaft, we notice this chamber opened together the shaft broken in the top.

Burial shaft 4 21a - 2V21-[A/f]:

Located is south burial shaft 3 . The shaft rectangular shape, the shaft cut in the limestone rock that constitutes the nature of the place and a layer of mother rock appears on those sides. In the floor $<\mathrm{A} / \mathrm{h}>$ of this well, $\mathrm{a}$ headless statue made of limestone was found on which inscriptions from the hieroglyphic texts appeared., it contained two burial chambers, the first is located on the north taked feature $21 \mathrm{a}-2721-[\mathrm{A} / \mathrm{i}]$, and it is semi-square in shape, in this chamber I found 5 wooden mask and part of wooden coffin broken, and the second is located on the right, taked feature 21a $2721-[\mathrm{A} / \mathrm{k}]$, and it takes the rectangular shape, we found in this chamber I found hug wooden coffin taked Fea\# 21a -2721-(A/x).

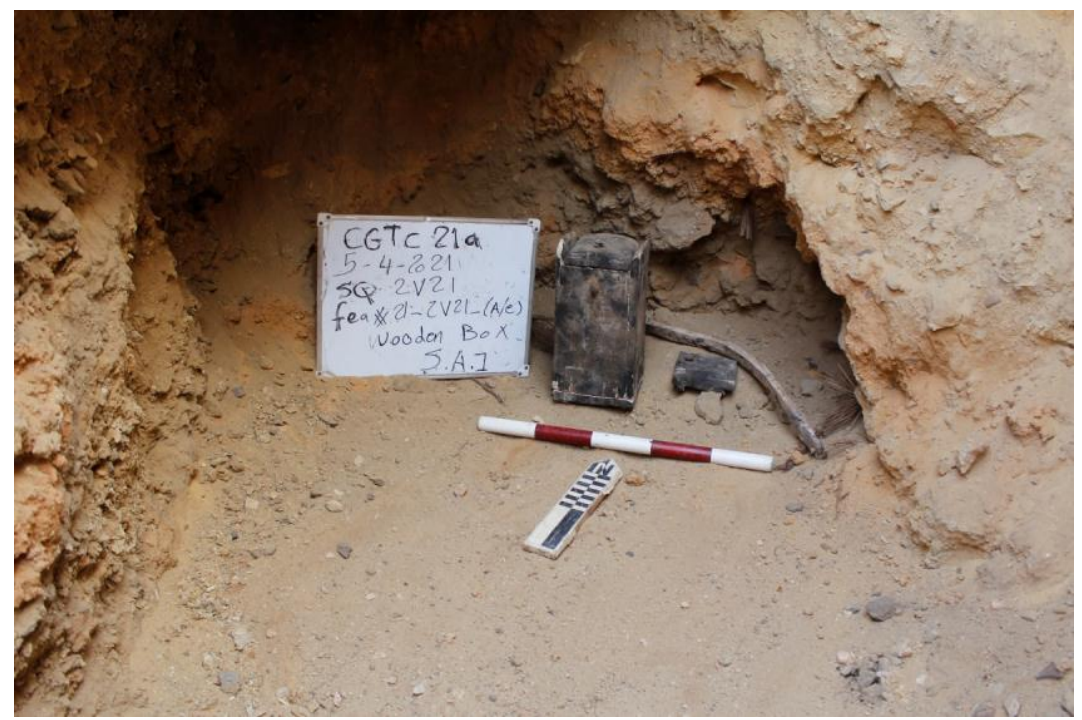

Burial shaft 5 21a - 2U21-[A/c]:

Located is south burial shaft 3 its rectangular shape facing east to west, its fill taking number $21 \mathrm{a}-2 \mathrm{U} 21-(\mathrm{A} / \mathrm{d})$, the shaft it contains 2 burial chamber in the west side from the shaft taking number $21 \mathrm{a}-2 \mathrm{U} 21-(\mathrm{A} / \mathrm{d})$ The two rooms are located behind one another. 
Sq\#2u20:

We complete the work in square $2 \mathrm{u} 20$; we excavate several layers, and found a cut $21 \mathrm{a}-2 \mathrm{u} 20-[\mathrm{A} / \mathrm{c}]$ and its fill is $21 \mathrm{a}-2 \mathrm{u} 20-(\mathrm{A} / \mathrm{d})$, during proses of excavation we found under cut taked fea\#21a-2u20-[A/e] the undercut lead to corridor fea\#21a-2u20- $<\mathrm{A} / \mathrm{i}>$ the corridor lead to chamber 8 fea\#21a-2u20-<A $/ \mathrm{k}>$, we found entrance lead to burial chamber 9 fea\#21a-2u20-<A $/ \mathrm{p}>$, when we finish excavated the burial chamber 9 we found entrance lead to burial chamber 10 behind the chamber we found entrance lead to chamber 11 and corridor we found inside it wooden box for bury fea\#21a-2u20-<A $/ y>$.

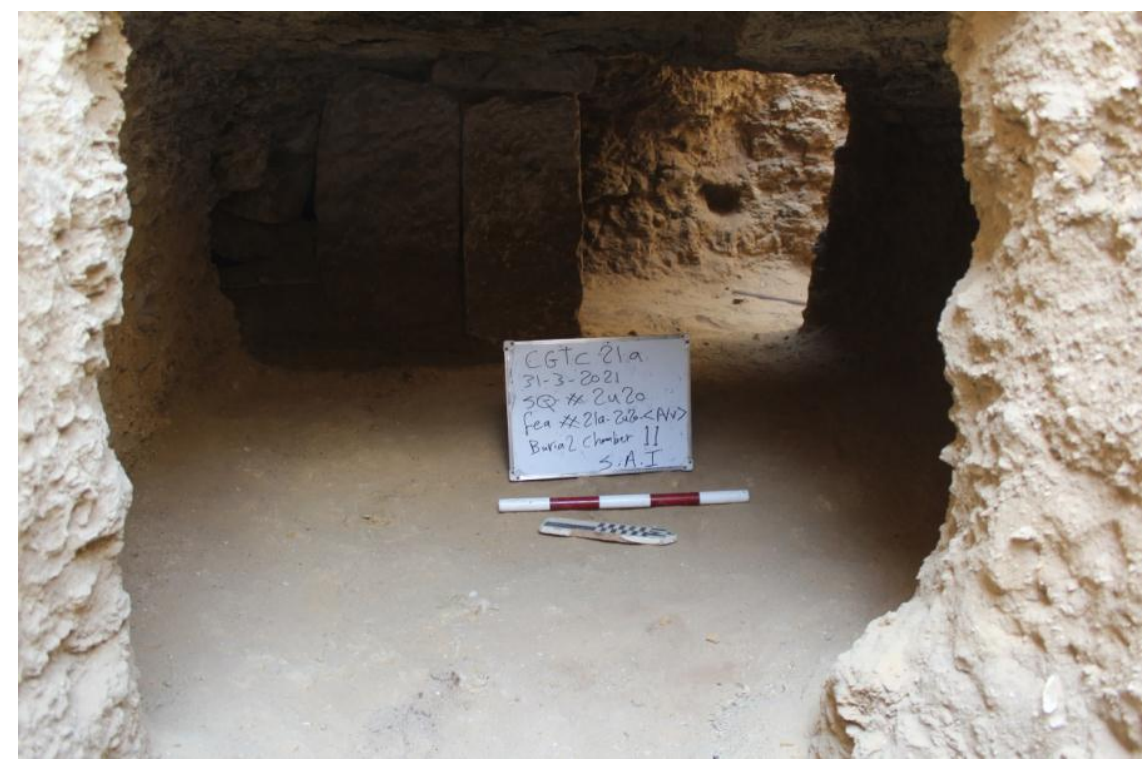


Important find object in the mastaba:

1- Part of Stela':

\begin{tabular}{|c|c|c|c|}
\hline Object. No. & $\begin{array}{l}\text { Kind of the } \\
\text { object }\end{array}$ & Place of the Finding & Square \\
\hline 1 & Part of Stela & North Saqqara & $2 u 20$ \\
\hline \multirow{2}{*}{$\begin{array}{l}\text { Place } \\
\text { preservation }\end{array}$} & \multirow{2}{*}{$\begin{array}{l}\text { Date } \\
\text { excavation }\end{array}$} & \multicolumn{2}{|l|}{ Photo the object instue } \\
\hline & & & \\
\hline $\begin{array}{l}\text { Not } \\
\text { completed }\end{array}$ & $3-3-2021$ & & \\
\hline \multicolumn{2}{|l|}{ Fea\# .No. } & & \\
\hline \multicolumn{2}{|c|}{$21 a-2 u 20-(A / f)-1$} & & \\
\hline
\end{tabular}

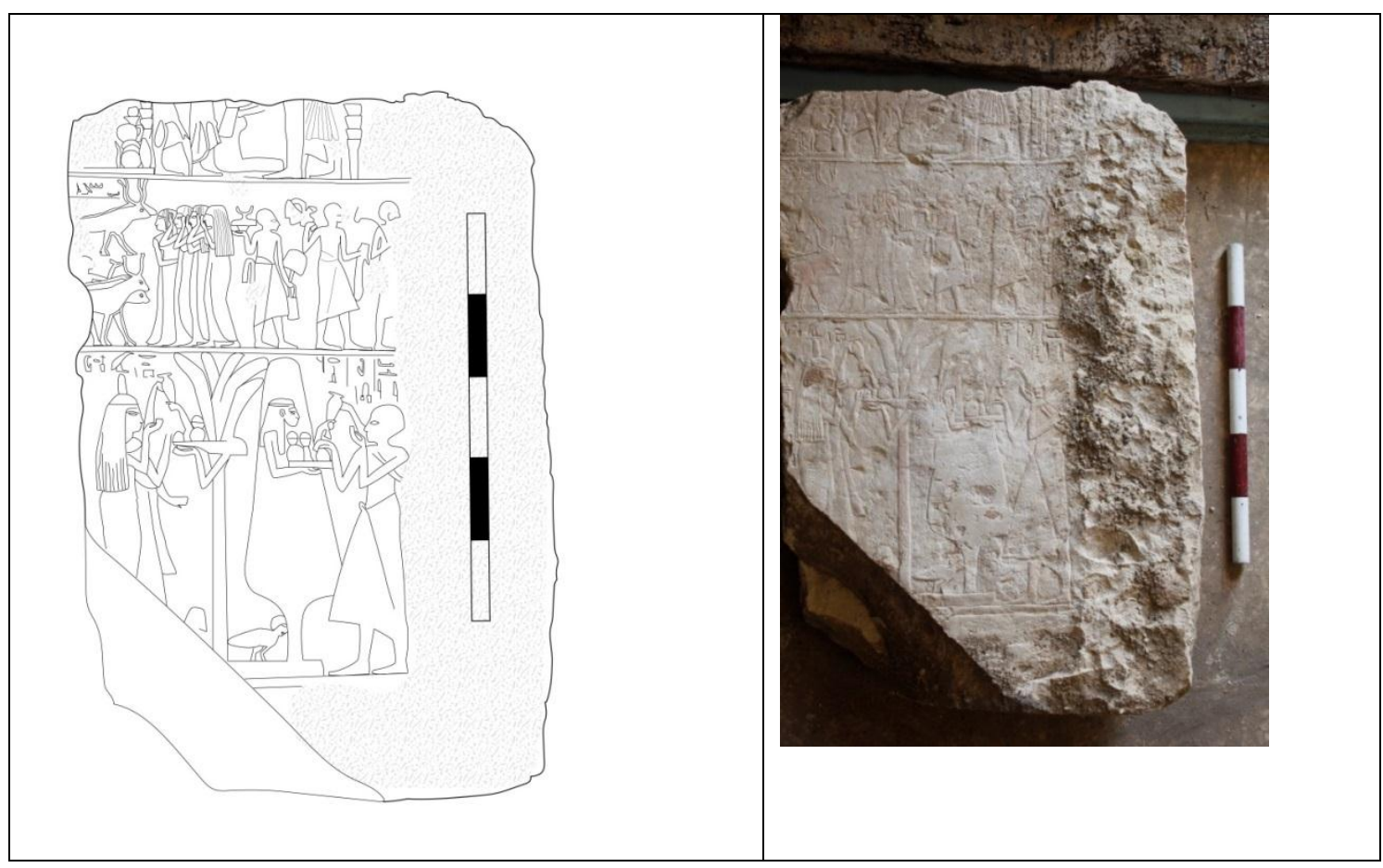

1 Stela is an independent piece of stone or wood with square, rectangular, or other shapes Regular in shape with flat tops or rounded tops and dimensions from several centimeters to several meters This is according to different ages, and bears inscriptions and drawings that serve the purposes for which these were prepared The paintings, the back surface of which is often left rough, have seldom been depicted on it wrote down texts. 
Comment:

The painting is a funeral panel, consisting of three records, the first upper register which is incomplete and carries in the content of offering sacrifices, and the second record includes a view of the funeral, where two men are shown on the right, one holding a headrest and the other carrying offerings, The appearance of mourners circulated their hands on the face, which appeared since the Old Kingdom and continued throughout the ancient Egyptian history, and this situation appeared as an for the word $i w^{l}$ and verb II 0 O are three women mourning for the soul The deceased appears in front of them and a group of bulls appears in front of them, while the last record on the lower side shows an idol leaving the sacred tree and in front of an offering table and holding his right hand over the pot of beer while perhaps the deceased person appears in front of him, and behind them a lotus tree emerges from which a hand gripping the pot of beer and an offering table presented to a deity The deity extends a hand to receive the liquid that comes out of the vessel, the deity wears a long wig. 


\section{$\underline{\text { Hand kinematics table }}$}

\begin{tabular}{|c|c|c|c|c|c|c|c|c|}
\hline \multicolumn{4}{|c|}{ Historical period } & | سفل فئن & 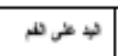 & 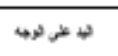 & أليد على الرأس & \\
\hline $\begin{array}{l}\text { Rigion } \\
\text { the king }\end{array}$ & $\begin{array}{l}\text { New king } \\
\text { dom }\end{array}$ & $\begin{array}{l}\text { Middle } \\
\text { king }\end{array}$ & $\begin{array}{l}\text { Oldking } \\
\text { dom }\end{array}$ & & & & & \\
\hline Six dyanasty & & & $\sqrt{ }$ & & & $\sqrt{ }$ & $\sqrt{ }$ & Ankh Ma Hoor \\
\hline Six dyanasty & & & $\sqrt{ }$ & & & & $\sqrt{ }$ & Idu \\
\hline Six dyanasty & & & $\sqrt{ }$ & & & & $\sqrt{ }$ & Mererouk \\
\hline \begin{tabular}{|l|} 
Amenhotep I \\
Thutmose III
\end{tabular} & $\sqrt{ }$ & & & & & & $\sqrt{ }$ & TT81 \\
\hline Thutmose III & $\sqrt{ }$ & & & & & & $\sqrt{ }$ & TT54 \\
\hline Thutmose III & $\sqrt{ }$ & & & & & $\sqrt{ }$ & & TT82 \\
\hline Thutmose III & $\sqrt{ }$ & & & & & $\sqrt{ }$ & & TT87 \\
\hline $\begin{array}{c}\text { Ramesside } \\
\text { period }\end{array}$ & $\sqrt{ }$ & & & & $\sqrt{ }$ & & & TT296 \\
\hline $\begin{array}{l}\text { Ramesside } \\
\text { period }\end{array}$ & $\sqrt{ }$ & & & $\sqrt{ }$ & & & & TT44 \\
\hline Merneptah & $\sqrt{ }$ & & & $\sqrt{ }$ & $\sqrt{ }$ & & & TT23 \\
\hline
\end{tabular}


2- Apart schist statue:

\begin{tabular}{|l|l|l|l|}
\hline Object. No. & $\begin{array}{l}\text { Kind of the } \\
\text { object }\end{array}$ & $\begin{array}{l}\text { Place of the Finding } \\
\text { statue }\end{array}$ & Square \\
\hline 2 & Date excavation & Photo the object instue \\
\cline { 2 - 4 } $\begin{array}{l}\text { Place lower } \\
\text { preservation }\end{array}$ & $14-3-2021$ \\
\hline $\begin{array}{l}\text { The } \\
\text { half of the } \\
\text { statue is } \\
\text { broken }\end{array}$ & & 2721 \\
\hline \begin{tabular}{l} 
Fea\# .No. \\
\hline \multicolumn{2}{|c|}{$21 \mathrm{a}-2721-(\mathrm{A} / \mathrm{m})$}
\end{tabular} \\
\hline
\end{tabular}

A Statue of a schist broken in the middle of a man resembling Nubian Features, Wearing a Wig, the eyes are wide, the noise is wide, the lips protruding, the chin is extended to the front, and he wears an ornate bodice that also shows olds of a robe on the shoulders. The goddess Isis is winged. There have been many references to the existence of Nubian mercenaries, ${ }^{1}$ such as the Winy papyrus, ${ }^{2}$ which indicates their presence since the Fifth and Sixth Dynasties, as well as the Dahshûr decree from the reign of King Pepi $\mathrm{I}$, and it is now preserved in the Berlin Museum. The statue, which is represented by the goddess of Nubian origin. ${ }^{3}$

1 Ibrahim Qadis, Mercenary soldiers in the Egyptian army in ancient Egyptian sources until the end of the era of the New kingdom.(sohag university 2007),24-30.

2M .El-Khadragy, "some paleographic feature of weni,s biography", in: GM 188,2002.61.

3 L.Borchardt, "konigerlab aus Dahshûr", in: ZAS 42(1905), 1-11. 


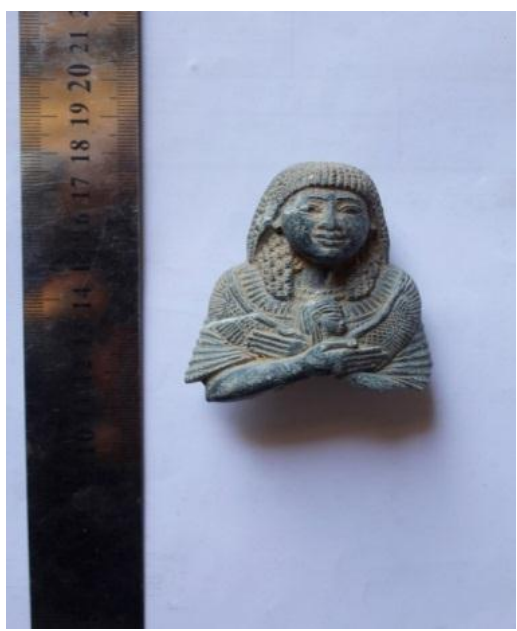

3-A wooden coffin inside an erased model of a mummy:-

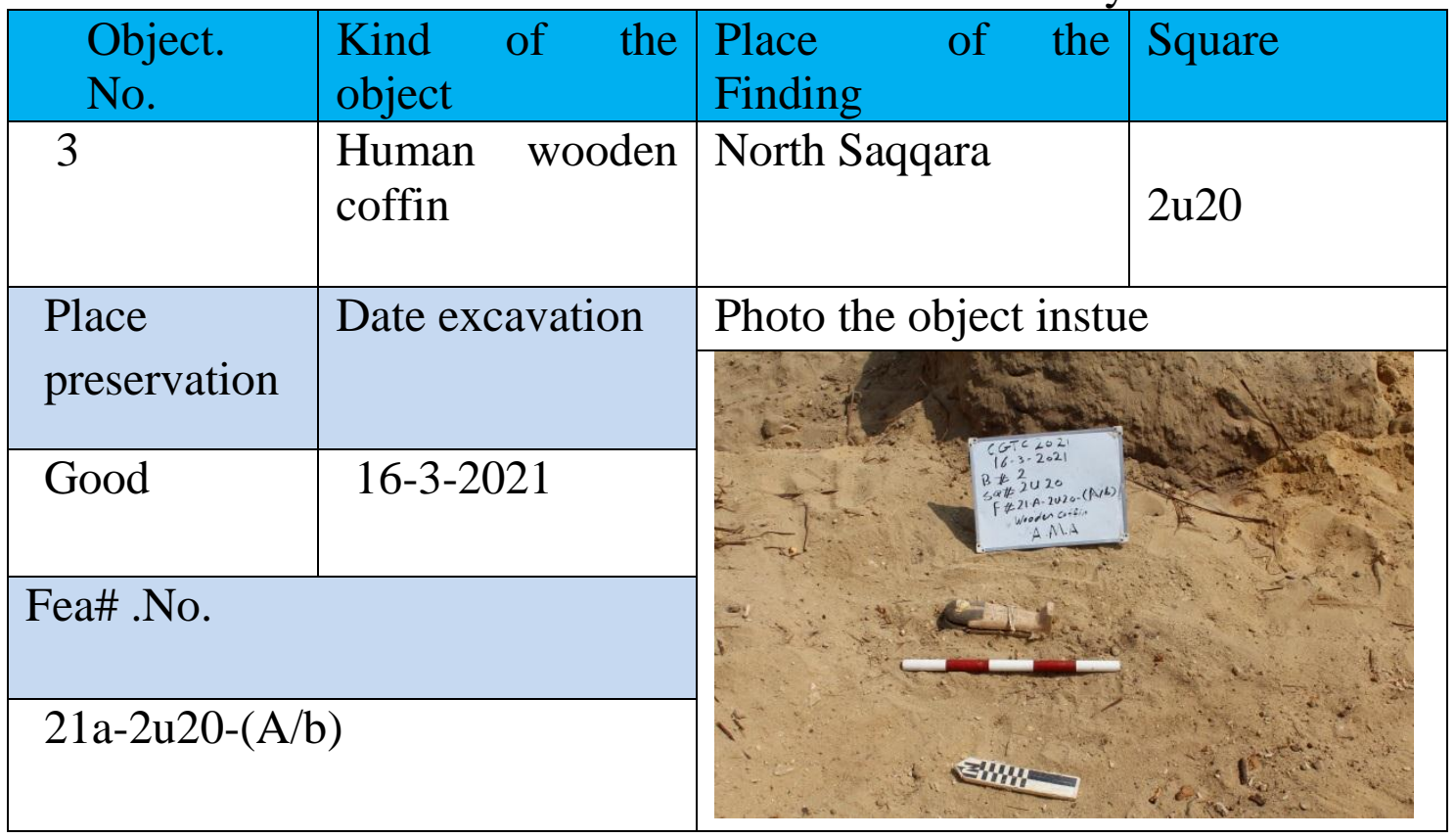



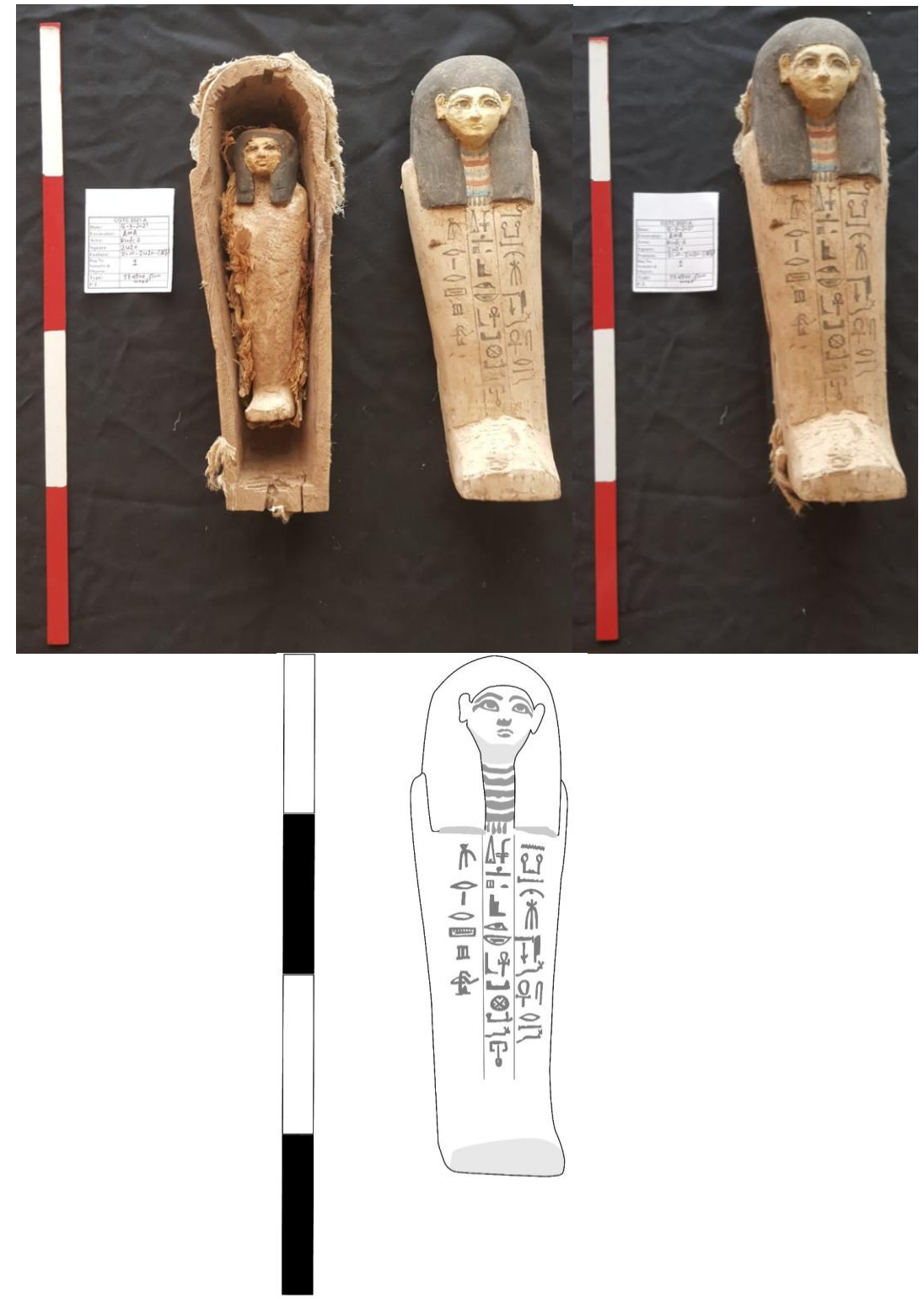

\section{Comment:}

Human coffins appeared at the end of the twelfth dynasty, where the ancient Egyptian formulated their idea through the appearance of funerary masks since the era of the old kingdom ${ }^{1}$.most of them were painted white and the chest area was decorated with a necklace of Egyptian sometimes painted the face in black to indicate the resurrection, as well as inlaying the eyes. The coffins of the middle human state were

$1 \mathrm{~S}$. Ikram., and A. Dodson., The Mummy in Ancient Egypt: Equipping Dead for eternity, (London1998),202-203. 
distinguished by the lack of embodiment of the hands. Say a word wt on human coffins. ${ }^{1}$

About A wooden coffin inside an erased model of a mummy discovered this season in sq\# $2 \mathrm{u} 20$ Fea\# $21 \mathrm{a}-2 \mathrm{u} 20-(\mathrm{A} / \mathrm{b})$. The coffin is inscribed on the sides of the inscription with hieroglyphs. The coffin is decorated with a long black headdress, and the eyes and eyebrows are defined, showing a bib, colored in blue and red. The hands disappeared inside the coffin.

\section{Inscription on the coffin:}

\begin{tabular}{|c|c|c|}
\hline موقع الكتابة & الترجمة & الدلالة الصوتية \\
\hline السطر 1 & 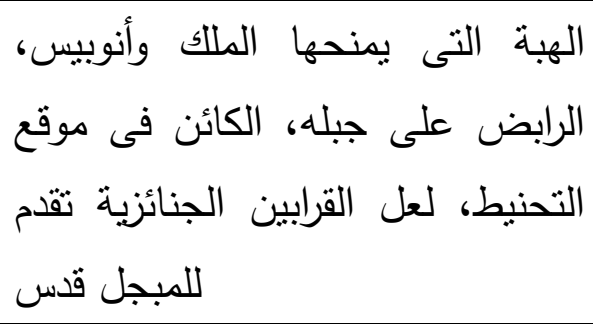 & $\begin{array}{l}\text { htp dj nswt wsir nb } 3 b d w \\
\text { di.f prt-hrw. }\end{array}$ \\
\hline السطر r & لروح "أحمس" بواسطة أخوه الحى. & $\begin{array}{l}N k 3 n i h-m s^{2} \text { in } s n . f s h \\
r n . f .\end{array}$ \\
\hline السطر r & جبا - رو - رش & $\underline{d} b 3 r r \check{s} p .^{3}$ \\
\hline
\end{tabular}

1 Wb. I, 379. 7.

2 Ranke, PN.I.12.

3 This line might be the brother's name, and it could be the surname + name. 


\section{1- Limestone offerings Stela ${ }^{1}:-$}

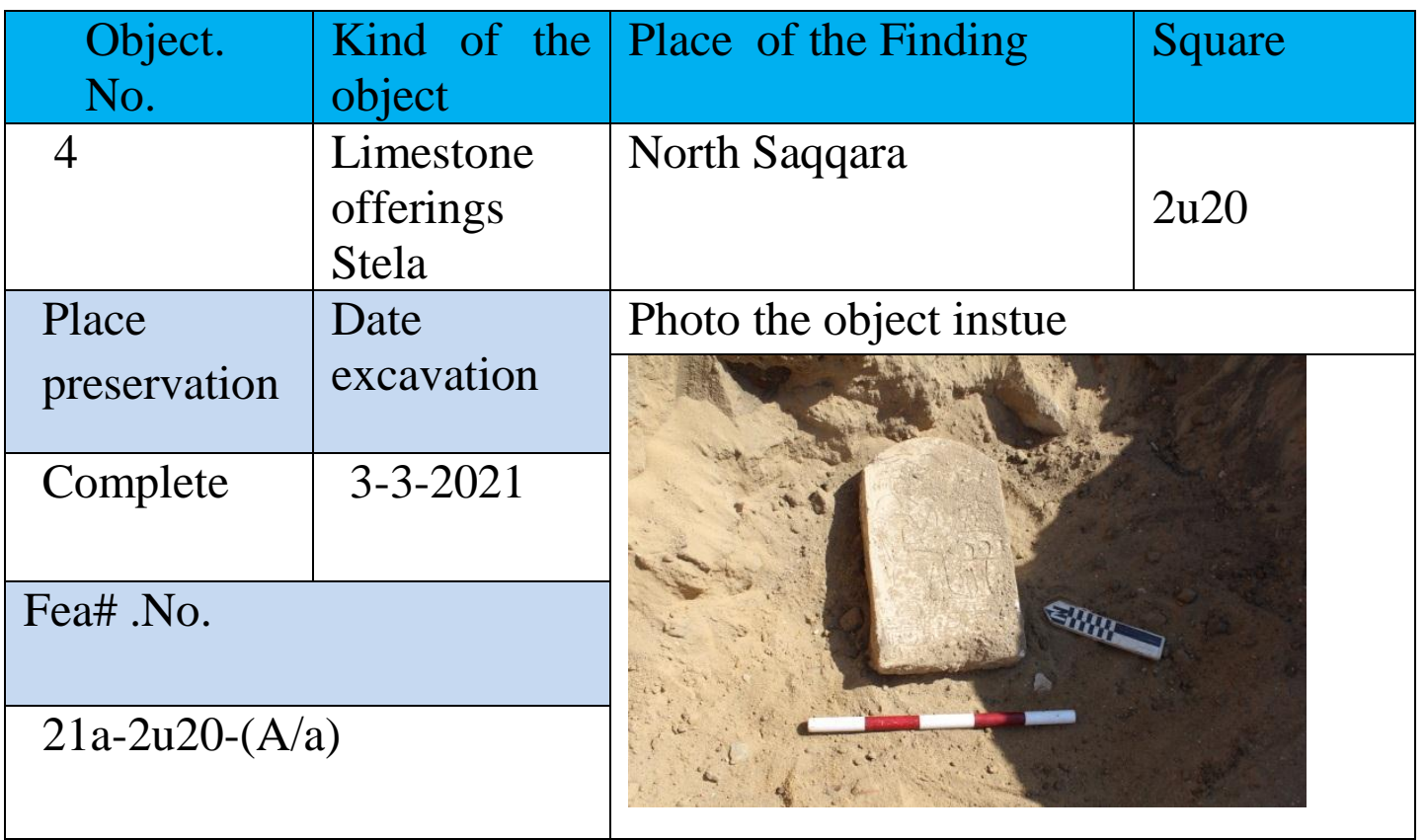

There are many important words in the ancient Egyptian language that appeared on the surfaces of paintings or on the surfaces of other monuments, which expressed the word painting such as the word

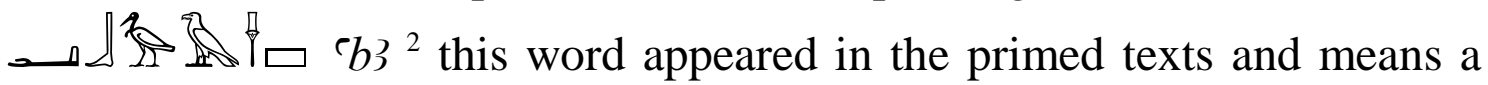
Stela or an offering, and mention word $P$ Q $w \underline{d}^{3}$ during middle kingdom period It means tombstone, border Stela, memorial Stela, or votive Stela. As for the allocations that came at the end of the words on the board, they refer either to the shape of the board as the custom $\_$which refers to the Stela with the rounded top as the model in front of us

1 Stylistic similarities: Vienna, KHM ÄS 159 (decoration and depictions in raised relief, but captions incised; shen-ring with antithetic udjat-eyes; similar attitude of the (main) person; early 18th Dynasty, CAA Wien 16, 64-66); Florence 2496 (similar composition; early 18th Dynasty); Florence 2511(similar to Vienna 159; early 18th Dynasty); Moscow 5629 (similar composition; early 18th Dynasty); Boston 05.97 (early 18th Dynasty; CAA Boston 3, 77-78); Brooklyn 07.420 (similar to Florence 2496; early 18th Dynasty); BM 466 [300], HT V/21 (17th Dynasty); BM 327 [1370], HT V/20 (early 18th Dynasty, though Budge believes it to be 13th-17th Dynasty); Leiden V 74 (early 18th Dynasty). For the inverse direction of the libation water cf. Vienna, KHM ÄS 137 and 5899 (CAA Wien 16, 43-48; 16, 113-119; 18th Dynasty).

2 WB I, 177 (7-9).

3 Müller, H.W., Loc. Cit; WB I, p. 398 (15-19). 
Round-topped Stela, or the allocations $\triangle$ that came at the end of the words on the board. Which refers to the plate with the top of the pyramid.

\section{Discovered Stela:}

The Stela is divided into 3 registers. The lunette shows two udjateyes flanking a shenring ${ }^{1}$.Then I engraved his vertical rows of hieroglyphs, the owner of the painting sits on a chair and has an armrest behind her. The chair is decorated with the legs of cattle. Her left hand holds a lotus flower and in front of it an offering table consisting of the upper part of some types of fruits and lotus flowers, and then the left thigh of the bull and three round-shaped loaves of bread carrying on the backrest and under them two containers for beer, ${ }^{2}$ and the last record is formed From the panel are three horizontal texts of hieroglyphic signs.

\begin{tabular}{|c|c|c|}
\hline فوقع الكتابة - موق & الترجمة & الدلالة الصوتية \\
\hline السطر & خادمة موت، الحى اسمها، سيدة & $\begin{array}{l}\text { hnwt in } m w t s^{\circledR} n h r n(. s) \\
\text { nbt pr iry. }\end{array}$ \\
\hline
\end{tabular}

\begin{tabular}{|c|c|c|}
\hline فوقع الكتابة & الترجمة & الدلالة الصوتية \\
\hline السطر I :r & قربان يعطيه الملك لسكر - أوزير الاله & 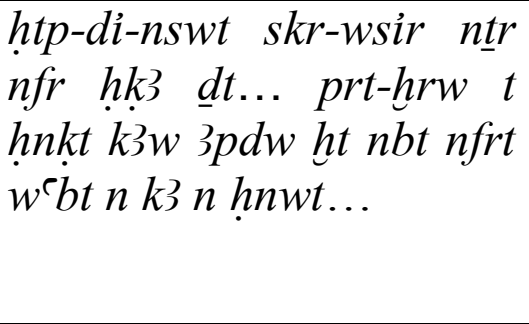 \\
\hline
\end{tabular}

1 R. HÖLZL, Die Giebelfelddekoration von Stelen des Mittleren Reiches, Beiträge zur Ägyptologie 10, Wien 1990, 16-17; 32.

2 The ancient Egyptians as a civilized nation used bread in their diet from as early as 6000 BC during the Predynastic era of their ancient history. 


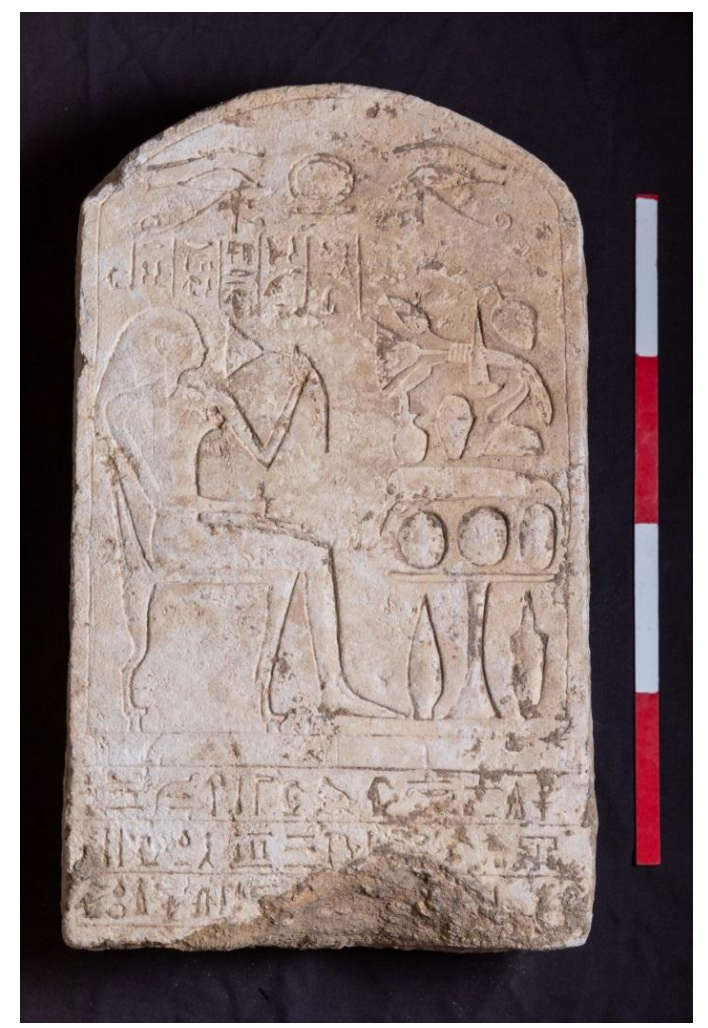

2- Oshabti statues from limestone broken:

Since the beginning of ancient Egypt times, tombs have been provided with otherworldly furniture to meet the needs of the deceased in the other world, and these things were initially simple such as food and drink, to meet the needs of the Oshabti appeared during the first intermediate period and increased in important during the middle kingdom period. ${ }^{1}$

As for the model of Oshabti statue we are referring to, it is one of the kinds of statues in which perfection appeared in the clarity of the anatomical proportion of the body and the appearance of the palms began. The types of statues dates back to the beginning of the middle kingdom and continued unite the period of the new kingdom. The Oshabti statues were intended to act in place of deceased in afterlife. ${ }^{2}$ 


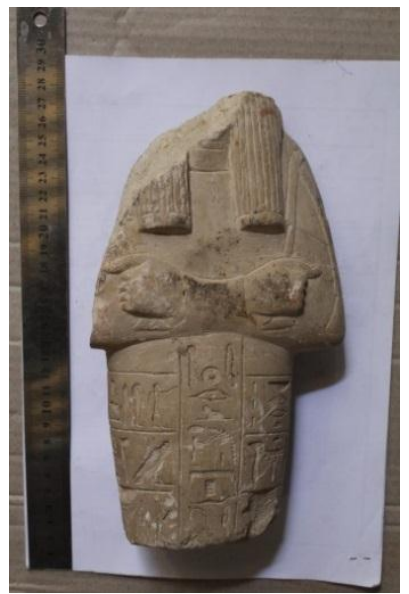

5-Wooden coffin human with mummy covered by textile:

\begin{tabular}{|l|l|l|l|}
\hline \multicolumn{1}{|c|}{ Object. No. } & $\begin{array}{l}\text { Kind of } \\
\text { the object }\end{array}$ & Place of the Finding & Square \\
\hline 5 & $\begin{array}{l}\text { Wooden } \\
\text { coffin }\end{array}$ & North Saqqara & $2 \mathrm{v} 21$ \\
\hline preservation & $\begin{array}{l}\text { Date } \\
\text { excavation }\end{array}$ & Photo the object instue \\
\cline { 1 - 1 } $\begin{array}{l}\text { No relief on } \\
\text { the wooden } \\
\text { coffin. }\end{array}$ & $14-3-2021$ & \\
\hline $\begin{array}{l}\text { Feature } \\
\text { 21a-2v21- } \\
(\mathrm{A} / \mathrm{m})\end{array}$ & & \\
\hline
\end{tabular}


The word coffin was known in the ancient Egyptian language tst it is a wooden coffin or a funerary vessel, the word g3wt appeared in the late stage of the ancient Egyptian language. ${ }^{1}$ During excavation process we discovered in sq\# $2 \mathrm{v} 21$ fea\# $21 \mathrm{a}-2 \mathrm{v} 21-(\mathrm{A} / \mathrm{c})$ Wooden coffin human with mummy covered by textile.

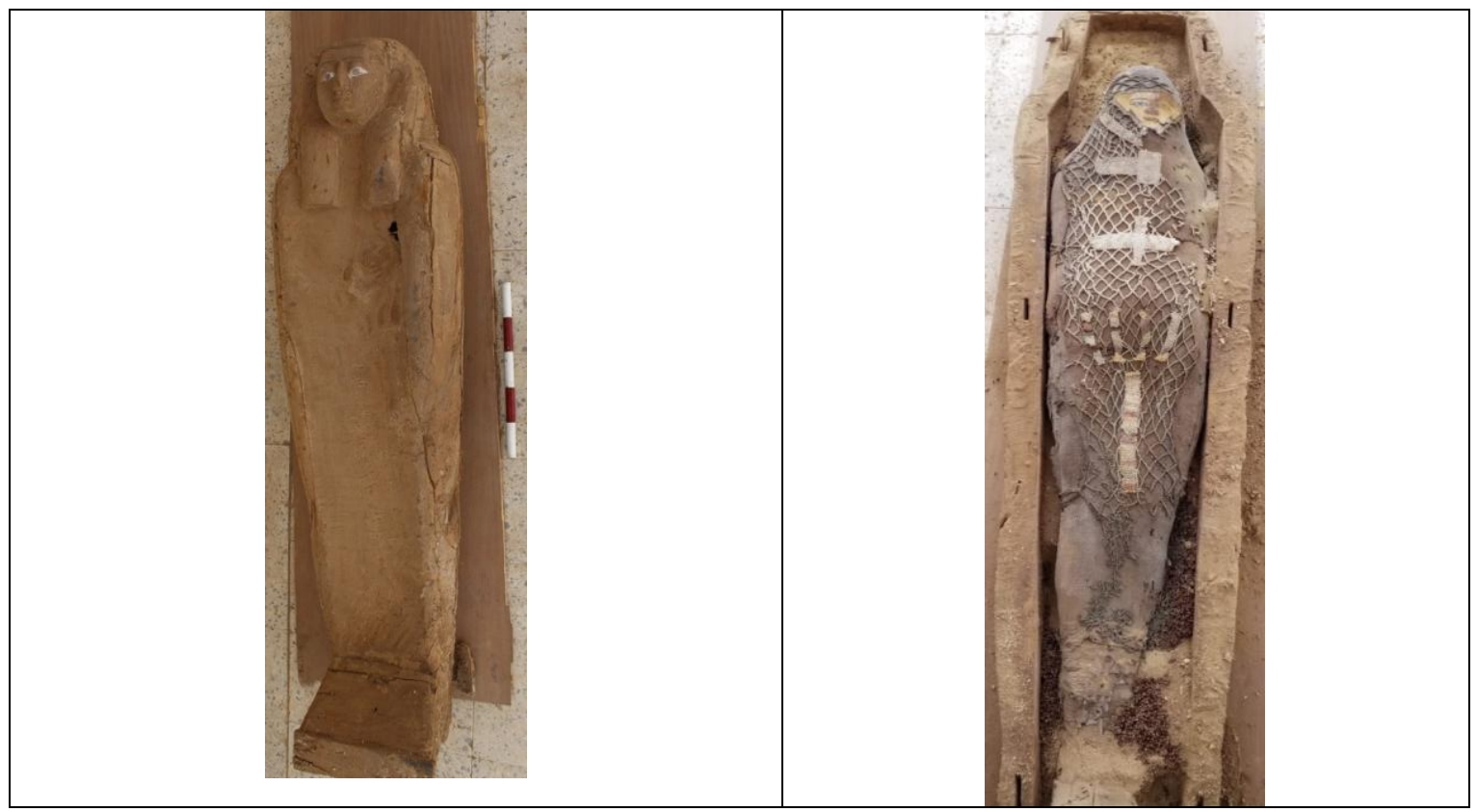

' أحمد على برقي بلال، التوابيت في العصر المتأخر ، r. 
3- Two Stela from the Sixth Dynasty period:-

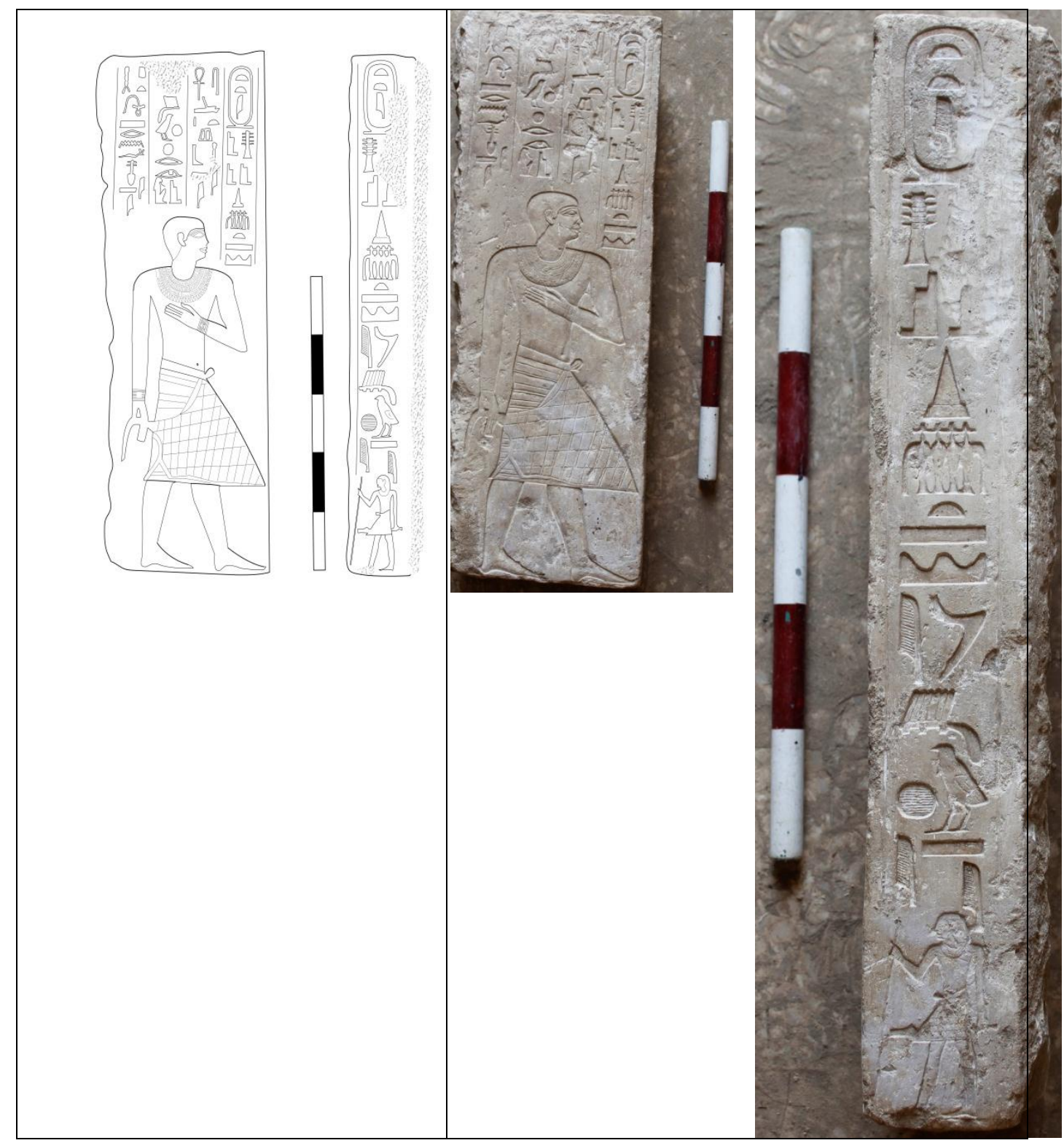


4- Wooden Oshabti Statue:

\begin{tabular}{|c|c|c|c|}
\hline Object. No. & $\begin{array}{l}\text { Kind of the } \\
\text { object }\end{array}$ & Place of the Finding & Square \\
\hline 7 & $\begin{array}{l}\text { Wooden } \\
\text { Oshabti Statue }\end{array}$ & North Saqqara & $2 u 21$ \\
\hline preservation & $\begin{array}{l}\text { Date } \\
\text { excavation }\end{array}$ & & \\
\hline $\begin{array}{lr}\text { Good } & \text { but } \\
\text { don't } & \text { relief } \\
\text { showed } & \\
\end{array}$ & $28-3-2021$ & & \\
\hline \multicolumn{4}{|l|}{ Fea\# .No. } \\
\hline $21 \mathrm{a}-2 \mathrm{u} 21-(\mathrm{A} / \mathrm{h})$ & & & \\
\hline
\end{tabular}

Comment:

5- Wodden oshabti statue:-

\begin{tabular}{|c|l|l|l|}
\hline \multicolumn{1}{|c|}{$\begin{array}{l}\text { Object. } \\
\text { No. }\end{array}$} & $\begin{array}{l}\text { Kind of the } \\
\text { object }\end{array}$ & Place of the Finding & Square \\
\hline 8 & $\begin{array}{l}\text { Wooden } \\
\text { Oshabti } \\
\text { Statue }\end{array}$ & North Saqqara & $2 \mathrm{u} 21$ \\
\hline preservation & $\begin{array}{l}\text { Date } \\
\text { excavation }\end{array}$ & & \\
\hline $\begin{array}{l}\text { Good but } \\
\text { don't relief } \\
\text { showed }\end{array}$ & $3-3-2021$ \\
\hline Fea\# .No. & & & \\
\hline $21 \mathrm{a}-2 \mathrm{u} 21-(\mathrm{A} / \mathrm{h})$ &
\end{tabular}




\section{Result:}

Excavations at North Sakkara between 2018 and 2021revealed in large measme the answer to these interesting questions. During these years, tomb after tomb Belonging to the kings and nobles of the First Dynasty until third Dynasty were examined, and although in every case the burials had been plundered in ancient times and the contents of the tombs scattered and broken, we noted in many cases fragments of eating Vessels and animal bones lying on the east side of the burial remains. As soon as North Saqqara is considered a burial area for the period of the early dynastic eras. Despite this, the stratigraphic sequence of that cemetery contained archaeological burials of the late period, where skeletal remains were found, whether they were human or animal, and after the late period layer was found the layer of the modern state and then the layer of the beginning of the dynasties.

In spite of that, those terraces were re-used for burials during the era of the New Kingdom and the late era, and the most emphatic evidence of this is the discovery of paintings dated in the Amarna era at this site, as well as the discovery of complete pottery vessels studied by Mr. Mohamed Atef, a pottery specialist at the Scientific Training Center in Cairo And Giza in Saqqara, and it has been proven that it dates back to the era of the New kingdom. 


\section{Reference:}

1- Francesco Raffaele Saqqara, Early Dynastic monuments (Dynasties 1-3), (2002).

2 - Ana Traverse, Saqqara, North, Early Dynastic tombs ,In Encyclopedia of the archaeology of ancient Egypt, , K Bard ed, (Rutledge: London - New York), P:854-859., 1999.

3- Colin Reader, An early dynastic ritual landscape at North Saqqara: An inheritance from Abydos? In' The Journal of Egyptian Archaeology'(2017), 2.

4- John Watson, the $1^{\text {st }}$ Dynasty Tombs of Saqqara in Egypt.

5- Rinus Ormeling, Revisiting Walter B. Emery at Saqqara: Exploring Emery's excavations, In a reevaluation of his field notes (1946-1956), Current Research in Egyptology 2016 Proceedings of the Seventeenth Annual Symposium, (Oxford 2017).1

6- Geoffrey John Tassie and Lawrence Stewart Owens. Standards Of Archaeological Excavation A Field Guide To The Methodology Recording Techniques And Convention, 2010.

7 - Stela is an independent piece of stone or wood with square, rectangular, or other shapes Regular in shape with flat tops or rounded tops and dimensions from several centimeters to several meters This is according to different ages, and bears inscriptions and drawings that serve the purposes for which these were prepared The paintings, the back surface of which is often left rough, have seldom been depicted on it wrote down texts.

8- Wb. I, 48 (17).

9- Wb. I, 57 (14).

10-CT., II, 234.

11-Ibrahim Qadis, Mercenary soldiers in the Egyptian army in ancient Egyptian sources until the end of the era of the New kingdom.(sohag university 2007),24-30.

12- M .El-Khadragy, "some paleographic feature of weni,s biography", in: GM 188,2002.61.

13- L.Borchardt, "konigerlab aus Dahshûr", in: ZAS 42(1905), 1-11. 
14- S. Ikram., and A. Dodson., The Mummy in Ancient Egypt: Equipping Dead for eternity, (London1998),202-203.

15- Wb. I, 379. 7.

16- Ranke, PN.I.12.

17- This line might be the brother's name, and it could be the surname + name.

18- Stylistic similarities: Vienna, KHM ÄS 159 (decoration and depictions in raised relief, but captions incised; shen-ring with antithetic udjat-eyes; similar attitude of the (main) person; early 18th Dynasty, CAA Wien 16, 64-66); Florence 2496 (similar composition; early 18th Dynasty); Florence 2511(similar to Vienna 159; early 18th Dynasty); Moscow 5629 (similar composition; early 18th Dynasty); Boston 05.97 (early 18th Dynasty; CAA Boston 3, 77-78); Brooklyn 07.420 (similar to Florence 2496; early 18th Dynasty); BM 466 [300], HT V/21 (17th Dynasty); BM 327 [1370], HT V/20 (early 18th Dynasty, though Budge believes it to be 13th-17th Dynasty); Leiden V 74 (early 18th Dynasty). For the inverse direction of the libation water cf. Vienna, KHM ÄS 137 and 5899 (CAA Wien 16, 4348; 16, 113-119; 18th Dynasty).

19- Müller, H.W., Loc. Cit; WB I, p. 398 (15-19).

20- See R. HÖLZL, Die Giebelfelddekoration von Stelen des Mittleren Reiches, Beiträge zur Ägyptologie 10, Wien 1990, 16-17; 32.

21- The ancient Egyptians as a civilized nation used bread in their diet $\begin{array}{lllll}\text { from a } & \text { arly } & \text { as } & 6000 & \text { BC }\end{array}$ during the Predynastic era of their ancient history.

22-James.T.G.H: An Introduction to Ancient Egypt, (London 1979), 168.

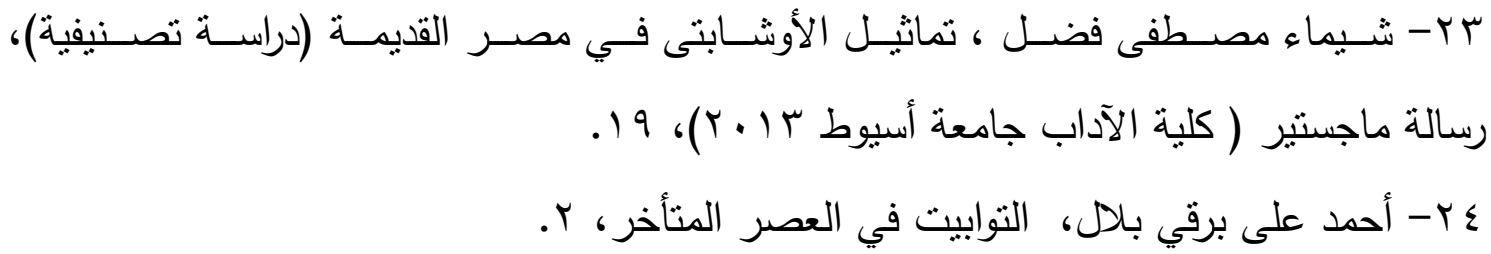

